\title{
EFEKTIVITAS EKSTRAK DAUN KEMANGI (Ocimum sanctum) SEBAGAI BIOLARVASIDA TERHADAP KEMATIAN LARVA Aedes aegypti TAHUN 2017
}

\author{
Febrina Dyta Pravitri ${ }^{*}$, Khomsatun $^{* *}$ ) \\ Jurusan Kesehatan Lingkungan, Politeknik Kesehatan Kemenkes Semarang, \\ Jl.Raya Baturaden KM 12 Purwokerto, Indonesia
}

\begin{abstract}
Abstrak
Penyakit Demam Berdarah Dengue salah satu penyakit endemis yang dapat menimbulkan wabah.Salah satu upaya yang penting adalah memutus rantai penularan, yaitu dengan menggunakan insektisida.Pengendalian vektor DBD umumnya menggunakan insektisida kimia yang berdampak negatif terhadap lingkungan.Penelitian ini dilakukan untukmengetahui efektivitas pengaruh berbagai konsentrasi ekstrak daun kemangi (Ocimum sanctum) terhadap kematian larva Aedes aegypti.Metode penelitian ini adalah quasi exsperiment dengan rancangan the posttest-only control group untuk menghitung kematian larva Aedes aegypti pada konsentrasi 0,3\%, 0,9\% dan 15\% ekstrak daun kemangi. Konsentrasi tersebut dimasukkan kedalam enamel berukuran 250 ml yang masing-masing berisi 25 ekor larva Aedes aegypti, diamati pada jam ke 1, 2, 3, 4, 5, 6 dan 24 jam.Hasil penelitian menunjukkan bahwa ada perbedaan berbagai konsentrasi ekstrak daun kemangi (Ocimum sanctum) dalam mematikan larva Aedes aegypti, untuk konsentrasi 0,3\% adalah 7 ekor (26,4\%), konsentrasi 0,9\% adalah 14 ekor $(54,4 \%)$ dan konsentrasi 1,5\% adalah 20 ekor (81,2\%).Simpulan penelitian ini adalah ekstrak daun kemangi dengan berbagai konsentrasi yang digunakan belum efektif karena belum mampu membunuh larva Aedes aegypti sampai $>90 \%$ selama 24 jam.Disarankan untuk peneliti selanjutnya dapat menggunakan konsentrasi ekstrak daun kemangi yang lebih tinggi.
\end{abstract}

Kata kunci: larva Aedes aegypti; ekstrak daun kemangi;kesehatan lingkungan

\begin{abstract}
The Effectivness of Basil Leaf Extract (Ocimum sanctum) as a Biolarvasida Against TheMortality of Aedes aegypti'sLarvae 2017. Dengue Hemorrhagic Fever is one of the most endemic disease that can lead to breakout. One important effort is to break the chain of transmission with the use of insecticides. Dengue vector control using chemical insecticides that are generally have a negative impact on the environment. The research was conducted to know the effectiveness of the influence of various concentrations basil leaf extract (Ocimum sanctum) against the mortality of Aedes aegypti's larvae. This research used quasi experiment method with the posttest only control group designto calculate the mortality of Aedes aegypti'slarvae at the concentrations $0,3 \%, 0,9 \%$ and $1,5 \%$ of basil leaf extract. The concentrationputs into the enamel of $250 \mathrm{ml}$ each containing 25 Aedes aegypti's larvae, were observed for 1, 2, 3, 4, 5, 6 and 24 hours. The result showed that there are differences of the influence of various concentrations basil leaf extract (Ocimum sanctum) in lethal of Aedes aegypti's larvae, for concentration 0,3\% are 7 tails (26,4\%), concentration $0,9 \%$ are 14 tails $(54,4 \%)$ and concentration $1,5 \%$ are 20 tails $(81,2 \%)$.The researcher concluded that the various of concentrations used basil leaf extract was not effective because not able to kill the Aedes aegypti's larvae by $>90 \%$ for 24 hours. Suggested for further research can use concentration of basil leaf extract higher.
\end{abstract}

Keywords:Aedes aegypti’s larvae; basil leaf extract; environmental health 


\section{Pendahuluan}

Menurut Hendrik L. Bloom (Notoatmodjo, 2007), derajat kesehatan dipengaruhi oleh empat faktor, yaitu : lingkungan, perilaku, pelayanan kesehatan dan keturunan. Dari keempat faktor tersebut, lingkungan mempunyai peranan yang sangat besar dalam upaya peningkatan derajat kesehatan masyarakat, terutama di negara berkembang.

Permenkes RI No. 374/MENKES/PER/III/2010 penyakit yang ditularkan melalui vektor masih menjadi penyakit endemis yang dapat menimbulkan wabah atau kejadian luar biasa serta dapat menimbulkan gangguan kesehatan masyarakat, sehingga perlu dilakukan upaya pengendalian atas penyebaran vektor.Salah satu penyakit yang dapat menimbulkan wabah atau kejadian luar biasa yaitu penyakit demamberdarah dengue.

Penyakit demam berdarah dengue adalah penyakit yang terdapat di daerah tropis, terutama di negara ASEAN dan Pasifik Barat.Vektor utama demam berdarah dengue adalah Aedes aegypti, sedangkan Aedes albopictus merupakan vektor potensialnya. Nyamuk Aedes aegypti adalah spesies yang berkembang biak pada tempat-tempat penampungan air bersih di dalam maupun diluar rumah (Indriantoro, 2014).

Kementerian Kesehatan RI mencatat jumlah penderita demam berdarah dengue di Indonesia pada bulan Januari-Februari 2016 sebanyak 8.487 orang penderita demam berdarah dengue dengan jumlah kematian 108 orang. Golongan terbanyak yang mengalami demam berdarah dengue di Indonesia pada usia 5-14 tahun mencapai $43,44 \%$ dan usia $15-44$ tahun mencapai 33,25\%. Hingga akhir Januari tahun ini, kejadian luar biasa penyakit demam berdarah dengue dilaporkan ada di 12 Kabupaten dan 3 Kota dari 11 Provinsi di Indonesia dan Kabupaten Banyumas masuk ke dalam daftar tersebut.

Hasil laporan Dinas Kesehatan Kabupaten Banyumas tahun 2016, pada bulan September 2016 sudah ada 1.247 kasus demam berdarah dengue. Bila dibandingkan periode yang sama tahun 2015, mengalami peningkatan signifikan dari 264 kasus demam berdarah dengue yang terjadi, atau ada peningkatan hingga 500 persen. Seluruh kecamatan yang ada di Kabupaten Banyumas sudah menjadi daerah endemik demam berdarah dengue.Jumlahnya ada 27 kecamatan sekitar ada 47 desa dan kelurahan yang menjadi daerah endemik.Jumlah ini naik 14 desa dan kelurahan bila dibandingkan tahun 2015 lalu.

Pemberantasan vektor demam berdarah dengue dengan menggunakan larvasida kimiatelah banyak menimbulkan dampak negatif antara lain peningkatan

\footnotetext{
${ }^{*}$ E-mail: elfebrina96@gmail.com

${ }^{* *}$ E-mail: khomsatun1962@gmail.com
}

resistensinyamuk, pencemaran lingkungan, keracunan, kematian makhluk bukanresidu (Murtanti \& Astuti, 2005).Ketertarikan untuk mengembangkan dan menggunakan insektisida yang alami, mudah didapatkan, serta aman bagi tubuh manusia dan lingkungan sekitar mulai dilirik sebagai bioinsektisida akhir-akhir ini.

Indonesia memiliki sumber keanekaragaman hayati yang sangattinggi, termasuk jenis tumbuhan yang mempunyai bahan aktif untuk dikembangkan sebagai larvasida nabati, senyawa yang terkandung dalam tumbuhan dan diduga berfungsi sebagai larvasida diantaranya adalah golongan sianida, saponin, tanin, flavonoid, alkaloid, minyak atsiri dan steroid (Kardinan, 2007).Salah satu tumbuhan yang memiliki senyawa aktif tersebut adalah daun kemangi.

Daun kemangi mengandung beberapa senyawa diantaranya alkaloid, flavonoid, saponin, tanin, tritepernoid dan minyak atsiri.Flavonoid, saponin dan tanin berguna sebagai racun perut yang dapat mengganggu kemampuan mencerna makanan pada serangga.Eugenol bertindak untuk menghambat reseptor perasa pada mulut larva (Gunawan, 2011).

Hasil penelitian Ustavian Hasanah (2010) menggunakan kemangi ungu sebagai larvasida nabati terhadap larva Anopheles aconitus dengan konsentrasi 0,6\% dapat mematikan 51\% larva, konsentrasi $1 \%$ dapat mematikan $71 \%$ larva, konsentrasi $1,4 \%$ dapat mematikan $85 \%$ larva, konsentrasi $1,8 \%$ dapat mematikan 92\% larva dan konsentrasi 2,2\% dapat mematikan 97\% larva. Peneliti berkeinginan untuk melanjutkan penelitian tersebut dengan konsentrasi yang lebih rendah dan subyek penelitian yang digunakan menggunakan larva Aedes aegypti.

Tujuan penelitian ini untuk mengetahui efektivitas pengaruh berbagai konsentrasi ekstrak daun kemangi (Ocimum sanctum) terhadap kematian larva Aedes aegypti.

\section{Bahan dan Metode}

Jenis penelitian yang digunakan adalah quasi experiment dengan rancangan the posttest-only control group. Penelitian ini membandingkan hasil eksperimen antara kelompok perlakuan yaitu ekstrak daun kemangi dan kelompok kontrol.

Besar sampel dalam penelitian ini adalah 25 ekor setiap unit perlakuan, dengan pertimbangan untuk eksperimen larva 20-25 ekor (WHO), pada masingmasing perlakuan.Banyaknya ulangan (replikasi) dalam penelitian ini adalah 3 kali.Enamel yang sudah diberi konsentrasi ekstrak daun kemangi 0,3\%, 0,9\%, 1,5\% dan kontrol yang berisi larva diamati pada jam ke 1, 2, 3, 4, 5, 6 dan 24 jam.

Pengumpulan data dilakukan dengan cara perhitungan dan pengukuran langsung pada objek yang diteliti. Perhitungan digunakan untuk mengetahui 
jumlah larva Aedes aegypti yang mati. Pengukuran digunakan untuk mengetahui suhu udara, kelembaban, suhu air uji dan $\mathrm{pH}$ air uji. Instrumen yang digunakan berupa beaker glass, pipet larva, thermo-hygrometer, portable multiparameter digital, timbangan analitik, stopwatch dan gelas ukur.

\section{Hasil dan Pembahasan}

Berdasarkan hasil penelitian terhadap kematian larva Aedes aegypti menggunakan berbagai konsentrasi ekstrak daun kemangi yang telah dilaksanakan pada tanggal 28 April - 6 Mei 2017 diLaboratorium Entomologi dan Insektarium Loka Litbang P2B2 Ciamis, dapat dilihat pada hasil dan pembahasan sebagai berikut :

\section{a. Jenis dan Jumlah Larva Penelitian}

Jenis larva penelitian yang digunakan dalam penelitian ini adalah larva Aedes aegypti Pangandaran instar III keturunan ke-1 yang diperoleh dari ruang rearing di laboratorium insektarium Loka Litbang P2B2 Ciamis.Jumlah larva yang digunakan dalam penelitian 300 ekor dengan masing-masing enamel berisi 25 ekor larva.

b. Ekstrak Untuk Penelitian

Pembuatan ekstrak dilakukan oleh pihak Loka Litbang P2B2 Ciamis dengan metode maserasi. Konsentrasi ekstrak daun kemangi yang digunakan dalam penelitian ini adalah $0,3 \%, 0,9 \%$ dan $1,5 \%$.

c. Suhu Udara Ruang Penelitian

Hasil pengukuran suhu udara rata-rata ruang penelitian adalah $28^{\circ} \mathrm{C}$. Menurut (Ditjen PP \& PL, 2007, h.11), suhu rata-rata optimum untuk perkembangan nyamuk adalah $25^{\circ} \mathrm{C}-27^{0} \mathrm{C}$. Toleransi terhadap suhu tergantung pada spesies nyamuknya, tetapi pada umumnya suatu spesies tidak akan bertahan lama bila suhu lingkungannya meninggi $5^{0}-6^{0} \mathrm{C}$ diatas batasdimana spesies secara normal dapat beradaptasi. Sehingga suhu udara rata-rata $28^{\circ} \mathrm{C}$ masih dapat diterima oleh larva.

d. Kelembaban Ruang Penelitian

Hasil pengukuran diketahui kelembaban udara rata-rata pada ruang penelitian adalah $82,5 \%$. Menurut (Ditjen PP \& PL, 2007, h.13) pada kelembaban < 60\% umur nyamuk akan pendek, sehingga tidakcukup untuk sikluspertumbuhanparasitdalam tubuh nyamuk. Kondisi ruang penelitian masih memenuhi syarat untuk kehidupan larva sehingga kematian larva bukan karena faktor kelembaban udara.

e. Suhu Air Uji

Menurut M.W.Service (2007 dalam Widya Candra, 2012), suhu air sangat berpengaruh pada kehidupan larva Aedes aegypti, suhu air yang standar untuk kehidupan larva adalah $25-30^{\circ} \mathrm{C}$. Berdasarkan hasil pengukuran suhu air uji sebelum dan sesudah pemberian perlakuan berupa ekstrak daun kemangi pada masing-masing perlakuan dan kontrol pada tabel1 yaitu suhu rata-rata sebelum penelitian $26^{\circ} \mathrm{C}$ dan suhu ratarata sesudah penelitian adalah $25^{\circ} \mathrm{C}$. Hal tersebut menunjukan bahwa suhu air uji tersebut mengalami penurunan $1^{0} \mathrm{C}$, suhu tersebut masih dalam rentang suhu air standar dan dapat diterima oleh kehidupan larva. Artinya suhu air uji selama penelitian masih sesuai dengan perindukan larva Aedes aegypti.

Tabel 1. Pengukuran Suhu Air Uji

\begin{tabular}{cccc}
\hline Konsentrasi & $\begin{array}{c}\text { Suhu Air Uji }\left({ }^{0} \mathrm{C}\right) \\
\text { Repli- } \\
\text { kasi }\end{array}$ & $\begin{array}{c}\text { Suhu } \\
\text { Sebelum } \\
\left({ }^{0} \mathrm{C}\right) \\
(5 \text { Mei 2017) }\end{array}$ & $\begin{array}{c}\text { Suhu } \\
\text { Sesudah } \\
\left({ }^{0} \mathrm{C}\right) \\
(6 \text { Mei 2017) }\end{array}$ \\
\hline \multirow{3}{*}{ Kontrol } & 1 & 26 & 25 \\
& 2 & 26 & 25 \\
& 3 & 26 & 25 \\
\hline \multirow{3}{*}{$0,3 \%$} & 1 & 26 & 25 \\
& 2 & 26 & 25 \\
\hline \multirow{2}{*}{$0,9 \%$} & 3 & 26 & 25 \\
\hline \multirow{3}{*}{$1,5 \%$} & 1 & 26 & 25 \\
& 2 & 26 & 25 \\
& 3 & 26 & 25 \\
\hline
\end{tabular}

f. $\quad$ pH Air Uji

Tabel 2. Pengukuran $\mathrm{pH}$ Air Uji

\begin{tabular}{lccc}
\hline $\begin{array}{l}\text { Konsen- } \\
\text { trasi }\end{array}$ & $\begin{array}{c}\text { Repli } \\
\text {-kasi }\end{array}$ & $\begin{array}{c}\text { pH Sebelum Air Uji } \\
\text { (5 Mei 2017) }\end{array}$ & $\begin{array}{l}\text { pH Sesudah } \\
\text { (6 Mei 2017) }\end{array}$ \\
\hline \multirow{2}{*}{ Kontrol } & 1 & 7,48 & 7,46 \\
& 2 & 7,48 & 7,47 \\
& 3 & 7,47 & 7,45 \\
\hline \multirow{2}{*}{$0,3 \%$} & 1 & 7,46 & 6,34 \\
& 2 & 7,46 & 6,37 \\
& 3 & 7,43 & 6,35 \\
\hline \multirow{2}{*}{$0,9 \%$} & 1 & 7,47 & 6,10 \\
& 2 & 7,48 & 6,12 \\
& 3 & 7,46 & 6,08 \\
\hline \multirow{2}{*}{$1,5 \%$} & 1 & 7,46 & 5,97 \\
& 2 & 7,44 & 5,98 \\
\hline
\end{tabular}

Larva Aedes aegypti dapat hidup di lingkungan air dengan $\mathrm{pH}$ 5,8 - 8,6 sehingga tidak menimbulkan gangguan fisik terhadap larva (Yulidar \& Zain Hadifah, 2014). Berdasarkan tabel 2 dapat diketahui pengukuran $\mathrm{pH}$ air sebelum dan sesudah pemberian perlakuan berupa ekstrak daun kemangi selama 24 jam penelitian menunjukan perubahan kadar $\mathrm{pH}$, penurunan kadar $\mathrm{pH}$ tidak terlalu signifikan dan masih dalam rentang standar pH air untuk kehidupan larva. Hal tersebut menunjukkan $\mathrm{pH}$ air tidak menimbulkan gangguan fisik pada larva 
sehingga dapat disimpulkan bahwa kematian larva pada saat penelitian bukan karena pengaruh $\mathrm{pH}$ air uji tetapi karena pengaruh kandungan senyawa yang terdapat pada ekstrak daun kemangi yang mampu membunuh larva Aedes aegypti.

g. Kematian Larva Aedes aegypti

Tabel 3.Data Kematian Larva Aedes aegypti Setelah Mendapat Perlakuan Ekstrak Daun Kemangi pada Konsentrasi (\%) dan Waktu (Jam)

\begin{tabular}{|c|c|c|c|c|c|c|c|c|}
\hline \multirow{2}{*}{$\begin{array}{l}\text { Konsen- } \\
\text { trasi }\end{array}$} & \multirow{2}{*}{$\begin{array}{l}\text { Re- } \\
\text { pli- } \\
\text { kasi }\end{array}$} & \multicolumn{7}{|c|}{$\begin{array}{c}\text { Lama Waktu Pengulangan (Jam) / } \\
\text { Kematian Larva Aedes aegypti }\end{array}$} \\
\hline & & 1 & 2 & 3 & 4 & 5 & 6 & 24 \\
\hline \multirow{3}{*}{ Kontrol } & 1 & 0 & 0 & 0 & 0 & 0 & 0 & 0 \\
\hline & 2 & 0 & 0 & 0 & 0 & 0 & 0 & 0 \\
\hline & 3 & 0 & 0 & 0 & 0 & 0 & 0 & 0 \\
\hline \multirow{3}{*}{$0,3 \%$} & 1 & 0 & 0 & 0 & 0 & 0 & 0 & 7 \\
\hline & 2 & 0 & 0 & 0 & 0 & 0 & 0 & 7 \\
\hline & 3 & 0 & 0 & 0 & 0 & 0 & 0 & 6 \\
\hline \multirow{3}{*}{$0,9 \%$} & 1 & 0 & 0 & 0 & 0 & 1 & 1 & 14 \\
\hline & 2 & 0 & 0 & 0 & 0 & 1 & 1 & 15 \\
\hline & 3 & 0 & 0 & 0 & 0 & 0 & 1 & 12 \\
\hline \multirow{3}{*}{$1,5 \%$} & 1 & 0 & 0 & 0 & 0 & 1 & 1 & 19 \\
\hline & 2 & 0 & 0 & 0 & 0 & 1 & 2 & 22 \\
\hline & 3 & 0 & 0 & 0 & 0 & 1 & 2 & 20 \\
\hline
\end{tabular}

Hasil pengamatan dan perhitungan pada tabel 3 kelompok kontrol tidak ada kematian larva Aedes aegypti. Adanya kematian larva Aedes aegypti menunjukkan bahwa ekstrak daun kemangi mampu membunuh larva di ketiga konsentrasi pada jam ke 5, 6 dan 24. Pada konsentrasi $0,3 \%$ selama 6 jam menunjukkan kematian yang sama, berbeda setelah jam ke 24. Konsentrasi $0,9 \%$ dan $1,5 \%$ menunjukkan kematian larva mulai meningkat pada jam ke 5, karena zat aktif yang terkandung dalam ekstrak daun kemangi sudah terakumulasi atau masuk ke dalam tubuh larva merusak pernafasan dan pencernaan larva, sehingga larva berubah menjadi pucat dan mengkondisikan tubuhnya sejajar dengan air agar mendapatkan oksigen, tetapi lama kelamaan akan mati. Suhu ruang lokasi penelitian adalah $28^{\circ} \mathrm{C}$ dan kelembaban udara ruang penelitian 82,5\%. Lamanya waktu digunakan untuk mengetahui seberapa lama ekstrak daun kemangi dapat mematikan seluruh larva dengan konsentrasi tersebut. Pada tabel 3 menunjukkan bahwa ekstrak daun kemangi pada 1 jam sampai dengan 4 jam tidak menunjukkan adanya beda atau kematian yang berarti, tetapi pada jam ke 5, 6 dan 24 menunjukkan adanya beda atau kematian larva yang berarti walaupun tidak mencapai $90-100 \%$.

Hasil pengamatan dan perhitungan penelitian yang dilakukan pada tabel 4 menunjukkan bahwa ratarata kematian larva Aedes aegypti pada kontrol adalah $0 \%$ dan setelah kontak ekstrak daun kemangi dengan konsentrasi $0,3 \%$ adalah 7 (26,4\%), sedangkan konsentrasi $0,9 \%$ adalah 14 (54,4\%) dan konsentrasi 1,5\% adalah $20(81,2 \%)$. Secara teoritis semakin tinggi konsentrasi dan waktu pemajanan maka semakin banyak jumlah kematian larva.

Tabel 4.Hasil Pengamatan Jumlah Kematian Larva Aedes aegypti

\begin{tabular}{|c|c|c|c|c|c|}
\hline $\begin{array}{l}\text { Kon- } \\
\text { sentrasi }\end{array}$ & $\begin{array}{c}\text { Repli } \\
\text {-kasi }\end{array}$ & $\begin{array}{c}\text { Jumlah } \\
\text { Larva } \\
\text { Uji }\end{array}$ & $\begin{array}{c}\text { Jumlah } \\
\text { Larva } \\
\text { Mati }\end{array}$ & $\begin{array}{c}\text { Rata- } \\
\text { Rata } \\
\text { Kema } \\
\text {-tian } \\
\text { Larva }\end{array}$ & $\begin{array}{c}\text { Rata- } \\
\text { Rata } \\
\text { Prosen- } \\
\text { tase } \\
\text { Kema- } \\
\text { tian } \\
\text { Larva } \\
(\%)\end{array}$ \\
\hline \multirow{3}{*}{ Kontrol } & 1 & 25 & 0 & \multirow{3}{*}{0} & \multirow{3}{*}{0} \\
\hline & 2 & 25 & 0 & & \\
\hline & 3 & 25 & 0 & & \\
\hline \multirow{3}{*}{$0,3 \%$} & 1 & 25 & 7 & \multirow{3}{*}{7} & \multirow{3}{*}{26,4} \\
\hline & 2 & 25 & 7 & & \\
\hline & 3 & 25 & 6 & & \\
\hline \multirow{3}{*}{$0,9 \%$} & 1 & 25 & 14 & \multirow{3}{*}{14} & \multirow{3}{*}{54,4} \\
\hline & 2 & 25 & 15 & & \\
\hline & 3 & 25 & 12 & & \\
\hline \multirow{3}{*}{$1,5 \%$} & 1 & 25 & 19 & \multirow{3}{*}{20} & \multirow{3}{*}{81,2} \\
\hline & 2 & 25 & 22 & & \\
\hline & 3 & 25 & 20 & & \\
\hline
\end{tabular}

Kematian yang bermakna dari larva Aedes aegypti menunjukkan bahwa ekstrak daun kemangi memiliki kemampuandaya bunuh terhadap larva Aedes aegypti. Kemampuan daya bunuh dari ekstrak daun kemangi tersebut dikarenakan kandungan kimia yang bersifat toksik dan antifeedant, yaitu : saponin, tanin, flavonoid dan eugenol, sehingga larva dapat terbunuh.

Cara masuk zat toksik kedalam tubuh larva dengan oral atau mulut, sehingga ekstrak daun kemangi yang dijadikan sebagai pengendalian larva nyamuk Aedes aegypti secara kimia (larvasida nabati) bekerja dengan sistem racunperut dan pernafasan. Hal ini karena kandungan kimia yang berada di dalam daun kemangi yaitu saponin, tanin, flavonoid dan eugenol yang masing-masing bersifat mengganggu alat pencernaan dan pernafasan dari larva nyamuk itu sendiri. Sehingga akhirnya membuat larva nyamuk tidak dapat mendapatkan asupan makanan, mencerna makanan dengan baik dan tidak mendapatkan oksigen sehingga terganggu pertumbuhannya yang lama kelamaan akan mati.

Kematian larva Aedes aegypti pada konsentrasi $0,3 \%$ adalah $26,4 \%$, konsentrasi $0,9 \%$ adalah $54,4 \%$ dan konsentrasi 1,5\% adalah 81,2\%. Menurut Komisi Pestisida Departemen Pertanian (1995) tentang metode standar pengujian efikasi pestisida konsentrasi yang efektif yaitu $>90 \%$ sehingga dapat disimpulkan pada hasil penelitian ini ekstrak daun kemangi dengan berbagai konsentrasi yang digunakan belum efektif karena belum mampu membunuh larva Aedes aegypti $>90 \%$ selama 24 jam. 


\section{h. Keterbatasan Penelitian}

Hal yang menjadi kendala atau keterbatasan saat penelitian adalah saat penelitian larva yang digunakan ada beberapa yang sudah menjadi instar IV, sehingga ada larva yang sudah hampir berubah menjadi pupa dan menjadi pupa dalam waktu kurang dari 24 jam dimana larva yang mulai menjadi pupa sudah tidak membutuhkan asupan makanan, sehingga larva tidak mati dan bertahan hidup yang menyebabkan kurang efektifnya konsentrasi yang digunakan dari ekstrakdaun kemangi tersebut.

i. Analisis Statistik

1) Uji Anova

Dari perhitungan statistik Anova yang diketahui bahwa nilai p (sig) $=0.000$ yang berarti < $<.05$ berarti Ha diterima atau ada perbedaan antara rata-rata kematian larva Aedes aegypti dari berbagai konsentrasi ekstrak daun kemangi yang diberikan.

2) Uji Probit

Dari hasil analisis Probit dengan tingkat kepercayaan 95\%, didapatkan estimasi besar konsentrasi yang mengakibatkan kematian larva Aedes aegypti sebesar 50\% $\quad\left(\mathrm{LC}_{50}\right)$ adalah konsentrasi $1,048 \%$ dengan interval antara 0,691\% dan 1,247\%. Sedangkan kematian larva sebesar 90\% $\left(\mathrm{LC}_{90}\right)$ didapatkan pada konsentrasi 2,084\% dengan interval antara $1,646 \%$ dan $4,897 \%$.

\section{Kesimpulan}

a. Ekstrak daun kemangi mampu membunuh larva Aedes aegypti pada konsentrasi 0,3\% adalah 7 ekor, konsentrasi 0,9\% 14 ekor dan konsentrasi $1,5 \%$ adalah 20 ekor.

b. Efektivitas ekstrak daun kemangi (Ocimum sanctum) untuk membunuh larva Aedes aegypti pada konsentrasi 0,3\% adalah 26,4\%, konsentrasi $0,9 \%$ adalah $54,4 \%$ dan konsentrasi $1,5 \%$ adalah $81,2 \%$.

c. Menurut Standar Pengujian Efikasi Pestisida konsentrasi efektif > 90\%. Hasil penelitian ini dapat disimpulkan bahwa ekstrak daun kemangi dengan berbagai konsentrasi belum efektif karena belum mampu membunuh larvaAedes aegypti sampai > 90\% selama 24 jam.

d. Hasil uji Anova menunjukkan signifikansi = 0.000 (< 0.05) yang berarti adanya perbedaan kematian larva Aedes aegypti akibat penggunaan berbagai konsentrasi ekstrak daun kemangi (Ocimum sanctum), yaitu semakin tinggi konsentrasi ekstrak daun kemangi yang digunakan maka semakin tinggi jumlah kematian larva Aedes aegypti.

e. Konsentrasi larvasida ekstrak daun kemangi (Ocimum sanctum) yang direkomendasikan dapat membunuh 50\% darisampel larva Aedes aegypti $\left(\mathrm{LC}_{50}\right)$ adalah $1,048 \%$ dan $90 \%$ dari sampel larva Aedes aegypti $\left(\mathrm{LC}_{90}\right)$ adalah 2,084\%.

\section{Ucapan Terima Kasih}

Peneliti mengucapkan banyak terima kasih kepada pihak Loka Litbang P2B2 Ciamis yang telah memberikan izin tempat penelitian dan membantu dalam pelaksanaan penelitian, serta seluruh pihak yang telah membantu terselesaikannya penelitian ini.

\section{Daftar Pustaka}

Agus Kardinan. 2007. Tanaman Pengusir dan Pembasmi Nyamuk. Agro Media Pustaka : Jakarta.

Arda Dinata. 2008. Atasi Jentik DBD dengan Kulit Jengkol.https://www.academia.edu/6610415/Ek strak_Kulit_Jengkol_Atasi_Jentik_DBD_Majal ah_Inside_Vol.III.No.02-Desember_2008 (Diakses tanggal 21/12/2016, pukul 17.16 WIB).

Aris Santjaka. 2011. Statistik Untuk Penelitian Kesehatan. Yogyakarta: Nuha Medika.

Aris Santjaka. 2015. Aplikasi SPSS Untuk Analisis Data Penelitian Kesehatan. Yogyakarta: Nuha Medika.

Badan Pengembangan dan Pembinaan Bahasa Kementrian Pendidikan dan Kebudayaan.2016. Pedoman Umum Ejaan Bahasa Indonesia.http://badanbahasa.kemdikbud.go.id/ lamanbahasa/sites/default/files/PUEBI.pdf (Diakses 11/01/2017, pukul 19.09 WIB).

Depdikbud Indonesia.1995. Kamus Besar Bahasa Indonesia Edisi Kedua.Jakarta : Balai Pustaka.

Departemen Kesehatan Republik Indonesia. 2007. Ekologi dan Aspek Perilaku Vektor. Jakarta : Direktorat Jenderal Pemberantasan Penyakit Menular Dan Penyehatan Lingkungan Pemukiman.

Departemen Kesehatan Republik Indonesia.2008. Modul Pelatihan bagi Pelatih Pemberantasan Sarang Nyamuk (PSN) DBD dengan Pendekatan Komunikasi Perubahan Perilaku/KKP.Jakarta : Ditjen P2PL.

DIT.JEN. PPM dan PLP, 1987, Pemberantasan Vektor dan Cara Evaluasinya.

Genis Ginanjar. 2004. Demam Berdarah.http //books.google.co.id/books/about/Demam_Berd arah.html?id=dZTuoqhfWdMC\&hl=id (Diakses tanggal 21/01/2017, pukul 22.01 WIB). 
Gunawan, E. 2011.Efek Potensial Larvasida Kombinasi Ekstrak Daun Kemangi (Ocimum sanctum Linn) dan Biji Jarak (Ricinus communis Linn) Terhadap Aedes aegypti.Skripsi.Surakarta : Universitas Sebelas Maret.

https://id.wikipedia.org/wiki/Aedes_aegypti diakses pada tanggal 17 Januari 2017 pada pukul 16.43 WIB.

https://id.wikipedia.org/wiki/Kemangi diakses pada tanggal 17 Januari 2017 pada pukul 16.56 WIB.

http://radarbanyumas.co.id/tag/demam-berdarah/ diakses pada tanggal 15 November 2016 pada pukul 19.40 WIB.

Indriantoro Haditomo. 2010. Efek Larvasida Ekstrak Daun Cengkeh (Syzygiumaromaticum L.) Terhadap Aedes aegypti L. Skripsi.Surakarta : Universitas Sebelas Maret.

Komisi Pestisida. 1995. Metode Standar Pengujian Efikasi Pestisida. Jakarta: Departemen Pertanian.

Kurnia Agung Indraprasta. 2015. Efektifitas Larvasida Antara Abate, Ekstrak Daun Sirsak (Annona muricata Linn) Dan Daun Sirih (Piper bitle Linn) Terhadap Kematian Larva Nyamuk Aedes aegypti Instar 3. Karya TulisIlmiah tidak diterbitkan.Purwokerto : Politeknik Kesehatan Kemenkes Semarang.

Murtanti, Astuti. 2005. Pengaruh Ekstrak Etanol Daun Mindi, Melia azedarach L.Terhadap Daya Tetes Telur, Perkembangan dan Mortalitas Larva Aedes albopictus. Jurnal Forum MIPA, vol.4, No.1 Juni 2005, Hal.13-20.

Ndione, R.D., O.Faye, M. Ndiaye, A. Dieye and J.M. Afoutou. 2007. Toxic Effects of Neem Products (Azadirachta indica A.) on Aedes aegypti Linnaeus 1762 Larvae. Affrican Journal of Biotechnology 6 (24): 2846-2854. Media Pustaka.

Sembel, Dantje Terno. 2009. Entomologi Kedokteran. Yogyakarta : CV Andi Offset.
Soekidjo Notoatmodjo. 2007. Promosi Kesehatan dan Ilmu Perilaku.Jakarta : Rineka Cipta.

Soekidjo Notoatmodjo. 2010. Metodologi Penelitian Kesehatan. Jakarta : Rineka Cipta.

Sudarsono et al. 2002.Tumbuhan obat II (hasil penelitian, sifat-sifat, dan penggunaannya).Yogyakarta : Pusat Studi Obat Tradisional Universitas Gadjah Mada.

Supartha, Wayan. 2008. Pengendalian Terpadu Vektor Virus Demam BerdarahDengue dalam Makalah Pertemuan Ilmiah Dies Natalis 2008. Bali :Universitas Udayana Fakultas Pertanian.

Susweni.2016. Keefektifan Pemakaian Ekstrak Daun Pepaya (Carica papaya) SebagaiInsektisida Alami Terhadap Kematian Larva Nyamuk Aedes aegypti, Karya TulisIlmiah tidak diterbitkan.Purwokerto : Politeknik Kesehatan Kemenkes Semarang.

Tri Cahyono. 2014. Pedoman Penulisan Proposal Penelitian dan Karya Tulis Ilmiah/Skripsi Edisi Revisi Ketiga. Purwokerto : Kementerian KesehatanRI Politeknik Kesehatan Jurusan Kesehatan Lingkungan Purwokerto.

Ustavian Hasanah. 2010. Daya Bunuh Ekstrak Daun Kemangi Ungu (Ocimum sanctum) Terhadap Larva Anopheles aconitus. Skripsi.Surakarta : Universitas Sebelas Maret.

Widya Candra Pertiwi. 2012. Pemanfaatan Ekstrak Daun Tomat (Solanum lycopersicum) Sebagai Insektisida Alami Untuk Mematikan Larva Nyamuk Aedes aegypti.Karya TulisIlmiah tidak diterbitkan.Purwokerto : Politeknik Kesehatan Kemenkes Semarang.

World Health Organization (WHO). 2005. Guidelines for Laboratory and Field Testing of Mosquito Larvasides.http://www.who.int/whopes/guideli nes/en/ (Diakses 21/01/2017 pukul 15.09 WIB).

Yulidar dan Zain Hadifah. 2014. Kerusakan Larva Aedes aegypti (Linn.) Setelah Terpapar Temefos Pada Fase Larva Instar 3 (L ). Jurnal Buski, vol.5, No.1 Juni 2014, Hal.23-28. 